\title{
The First Issue
}

\section{Volume 1, Number 1}

\section{Jeffrey Felton}

Professor of Microbiology, College of Osteopathic Medicine of the

Pacific, Western University of Health Sciences, Pomona, CA, USA

$\mathrm{F}$

rank Eaton conceived the idea of a free, peer-reviewed,

high-quality, advertiser-supported scientific journal. Instead of being organized around a particular scientific discipline, the journal would be organized around laboratory methods, something essential for all disciplines. Frank's background was in sales and advertising. He was a hearty fellow brimming with confidence and enthusiasm. For many years prior to BioTechniques, there had been free "throwaway" journals in clinical medicine. These were neither peer-reviewed nor very good journals.

In 1982, I was a post-doctoral fellow at Harvard Medical School in the laboratory of Jack Murphy, working on bacterial pathogenesis. Jack and Jean Nichols (a more-senior post-doc who later became his wife) had some connections with Seragen (a Boston-area company sold to Ligand Pharmaceuticals in 1998). Jean knew a marketing executive at Seragen named Phil Norton, and Phil was a customer of Frank's advertising business. It was through this chain of acquaintances that Frank Eaton came to ask me to join the Editorial Review Board of BioTechniques. How many post-docs are asked to join journal editorial boards, even of journals that do not yet exist?

I first met Frank Eaton in November 1982, over a lunch at Children's Hospital in Boston. Besides Frank and me, the other people present at the table were Tom Maciag (also of Harvard Medical School, who would also join the Editorial Board), and Phil Norton (a potential advertiser and an early supporter of the project), who worked at Seragen. A bit later, Frank also recruited Kathelyn Steimer (Stanford Medical Center) and Alan Runck (Technicon Instruments) to the Board.

At that first meeting, we talked about classes of articles we would publish: we would focus on molecular biology. "BioFeatures" would be full-length peer-reviewed articles; "Benchmarks" would be short notes; and we would call letters to the editor or brief lab tips "BioFeedback." I suggested that we should also include a review article; we would call this the "Overview." The article categories have changed over the years; the scientific focus has not.

For the Overview in the first issue (March/April 1983), I solicited "The Chemical Synthesis of Oligodeoxyribonucleotides" from
Tom Atkinson of the University of British Columbia. Though oligonucleotides were commonly used at that time, hardly anyone made their own. Atkinson's article was the first to present the core information on synthesizing oligodeoxyribonucleotides in a simple, accessible review. Looking back, the early 1980s were a sort of watershed time, between the days when scientists did everything for themselves and the current time when almost everything is bought in a kit or sent out to be done by a service provider. When I started working as a research technician at MIT in 1971, we recrystallized our own cesium chloride, redistilled our own phenol, boiled our own dialysis tubing, acid-washed our own Lang-Levy micropipettes, and certainly poured our own gels. I am not saying that was a more productive way to do things, but it was different from the way it is now.

As we were putting together that first issue, I observed that the well-known host strain JM103 (Joachim Messing's M13 cloning vector system) had some characteristics that did not match its published genotype. I phoned Messing, and after some discussion we agreed that the strain contained a P1 prophage that was not supposed to be there. This was a potential problem, since P1 encodes a DNA restriction system. And, though JM103 was supposed to be K12-restriction-negative, it in fact contained the $\mathrm{K} 12$ restriction-modification system. I wrote this up as the first BioFeedback for the first issue, and also constructed a derivative of JM103 that was cured of the P1 prophage.

The first issue also included "Successful In Vitro Primary Immunization of Human Peripheral Blood Mononuclear Cells and Its Role in the Development of Human-Derived Monoclonal Antibodies" by Joy Cavagnaro and Michael Osband. During production, Dr. Osband called Frank: he was having second thoughts. He wondered whether BioTechniques could succeed in the long haul, and worried that he might be left with an orphaned article published in an uncitable journal. I don't remember exactly how we persuaded him, and other authors who from time to time had the same fears in the early days, but we did.

When I joined the Editorial Board, Frank had already used various contacts to line up articles for the first issue of BioTechniques. But the second issue, scheduled for May/June 1983, was going to be tough. In order to publish the second issue on time, we needed to have all the articles not only lined up, but also in hand, well before May. We really had to get to work beating the bushes to find the articles we needed in order to publish the second issue. Tom Maciag recruited a colleague of his, Robert Weinstein, of Beth Israel Hospital, to submit an Overview on serum-free culture of normal mammalian cells. Kathy Steimer contributed a research article on a similar topic. Phil Norton provided an article on cell sorting, I wrote a BioFeedback on the use of citrate to protect Escherichia coli from phage lambda infection, and Tom wrote one on culturing difficult cells. BioTechniques Number 2 actually appeared as the 


\section{The First Issue}

June/July issue. That was the only issue of BioTechniques that was ever published late. Things rapidly got easier. It was surprising how quickly BioTechniques became recognized as a respected journal in which scientists wanted to publish their methods articles, and we never again had to solicit research articles to be able to publish. In 1983, we were not yet using computers to prepare BioTechniques for publication. Manuscripts were submitted, reviewed, and edited as typewritten hard copies. When they were ready for publication, we sent them to an outside company for typesetting and then received them back as galley proofs for a final proofreading.

In that first year, we published four issues on an approximately bimonthly schedule. In 1984, we made it five issues, skipping July/August. In 1985 and 1986 we published six bimonthly issues each year. In 1987 we published eight issues. In 1988 and 1989 we got up to 10 issues, and in 1990, we reached 12-where we have remained ever since. (In the process, I learned that success, like struggle, brings its own challenges. Advertising grew along with the submissions and, like any successful commercial journal, BioTechniques had to learn where to strike the balance between advertising and editorial. Ultimately, Frank agreed to limit advertising pages to no more than $50 \%$ of the journal.)

Early in this process, I began to take a leading role in the Editorial Board. Before long, I was reviewing, editing, and proofreading all of the articles published in BioTechniques. Many of the articles were outside of my field, so this was a real learning experience. Kathy Steimer and then Tom Maciag left the Editorial Board (though Tom would later return). By January 1984, the Editorial Board consisted of Alan Runck, Phil Norton, Robert Weinstein, and me (even though I had moved to the University of California, San Franciso).

Toward the end of 1983, BioTechniques hired its first full-time editorial staff, when Natania Mlawer signed on as managing editor to correspond with the authors and bring the journal issues to publication once the reviewing and editing were completed. In the spring of 1986, the journal hired its first scientific editor, Patricia F. Dimond. Pat brought a strong biology background and a more active role in dealing with authors, expanding the Editorial Board, and helping to guide the direction of the journal. Pat and I began to rebuild the Editorial Board by continuing to recruit from the growing pool of authors who had published articles in BioTechniques. Patricia Dimond continued as scientific editor through the end of 1988; James Ellingboe succeeded her. I continued to serve on the Editorial Board of BioTechniques until the end of 2001.

When a method is innovative and useful, it will be adopted by many laboratories and cited repeatedly. For BioTechniques, this began slowly and accelerated as the years went by. Many BioTechniques articles have been cited hundreds, and in some cases thousands, of times. During the period from 1983 to 1988, the most cited articles were overwhelmingly for methods in areas related to molecular biology. These included improved DNA sequencing protocols, automated DNA sequencing, cloning vectors including retroviral and adenoviral expression vectors, polymerase chain reaction, rapid cloning methods, isolation of DNA fragments from agarose gels, site-directed mutagenesis, blotting of protein and nucleic acids, nucleic acid hybridization and hybridization probes, purification of polyAcontaining RNA, CAT and luciferase reporter genes, antisense regulation, transfection, and electroporation. Some exceptions to this strong pattern include articles on cell culture, automated assays, and synthesis of multiple peptides, but gene-based molecular biology was clearly dominant.

I was lucky to fall into this opportunity back in 1982, and I am grateful to Frank Eaton for the chance to serve on the Editorial Board of BioTechniques and to help in getting this enterprise off the ground. I learned a lot from it, I enjoyed working with a lot of top-notch people, and I am proud of what we have all accomplished together. 